\title{
Public Support of Agricultural Risk Management - Situation and Prospects
}

\author{
V. Vilhelm ${ }^{1}$, J. Špička², A. Valder ${ }^{3}$ \\ ${ }^{1}$ Institute of Agricultural Economics and Information, Prague, Czech Republic \\ ${ }^{2}$ Faculty of Business Administration, University of Economics, Prague, Czech Republic \\ ${ }^{3}$ Faculty of Economics and Management, Czech University of Life Sciences Prague, Czech Republic
}

\begin{abstract}
Anotace
Cílem článku je vyhodnotit vývoj podpory řízení rizik v zemědělství v České republice v období 2001 - 2013. Článek rovněž naznačuje možný budoucí vývoj podpory řízení rizik v ČR. Data poskytnutá Podpůrným garančním rolnickým a lesnickým fondem (PGRLF) a Českou asociací pojištoven (ČAP) byla vyhodnocena metodami popisné statistiky (aritmetický průměr, směrodatná odchylka, variační koeficient). Zdrojem dat pro mezinárodní srovnání byly sekundární informace získané z výzkumných center Evropské komise. Autoři konstatují, že podpora řízení rizik v ČR po roce 2014 nebude využívat evropské fondy z Programu rozvoje venkova. Podpora bude založena na národních finančních zdrojích, bud' ve formě přímé podpory (subvence pojistného, ad hoc podpory) nebo nepřímé podpory preventivního charakteru (nákazový fond, obnova genetického potenciálu). Za účelem eliminace neočekávané potřeby ad hoc pomoci je nanejvýš žádoucí založit a průběžně doplňovat fond pro krytí katastrofických rizik, která nemohou být zvládnuta zemědělci ani pojišt'ovnami. Fond by měl být přístupný pouze zemědělcům, kteří průběžně proaktivně přistupují $\mathrm{k}$ řízení rizik.
\end{abstract}

\section{Klíčová slova}

Zemědělské pojištění, veřejná podpora, vzájemné fondy, stabilizace příjmů.

\begin{abstract}
The aim of the article is to evaluate the development of risk management support in agriculture in the Czech Republic in the period 2001 - 2013. The article also tries to outline some possibilities for the future risk management scheme in the Czech Republic. Data provided by the Support and Guarantee Agricultural and Forestry Fund (PGRLF) and the Czech Insurance Association (ČAP) was described using descriptive statistical methods (mean, standard deviation, coefficient of variation). The data sources for international comparison come from secondary sources made by the research centres for European Commission. Authors identify that risk management support in the Czech Republic after 2014 will not use EU funds from the Rural Development Programme. It will depend on national financial sources, either in the form of direct support (premium subsidies, ad hoc aids) or indirect support of prevention (disease fund, recovery fund). In order to eliminate unexpected need for ad hoc aid, it is highly desirable to establish and continuously contribute a fund for covering catastrophic risks which cannot be managed by farmers or insurance companies. Such fund should be eligible only for those applicants who continuously take risk management measures.
\end{abstract}

JEL classification: Q10, Q14, G22

\section{Key words}

Agricultural insurance, public support, mutual funds, income stabilization.

\section{Introduction}

Agricultural insurance is one of the most important risk management tools worldwide. Crop insurance with a $90 \%$ share of agricultural insurance premiums, plays a significantly more important role than the livestock insurance (with $4 \%$ share) worldwide (Iturrioz, 2009). This is because a compensation for the ordered destruction of animals in the case of an outbreak of dangerous 
diseases is usually legally mandatory ${ }^{1}$ from public sources.

It is more widespread in developed countries which have good access to insurance and reinsurance markets. Agricultural insurance in developed countries originates in named peril products that were originally offered by private companies approximately two hundred years ago, first in Europe and then in the United States. Today, many complex agricultural insurance products are offered, most of them heavily subsidized by governments (Smith, Glauber, 2012).

The complexity of agricultural insurance and the rate of its public support depend on the risk exposure of regions. In the Europe, the Euro-Mediterranean countries are the major risk contributors. These countries not only have the highest expected loss but also high volatility of indemnity payments. On the contrary, the Nordic countries have the lowest indemnity payments and risk exposure (Yildirak, Gulseven, 2012).

The public support of agricultural insurance should encourage farmers to increase the use of agricultural insurance, to provide financial stability to farmers and other actors in the agri-value chain and to promote agricultural investment and access to credit in vulnerable regions. Farmers can exploit public support in many forms. Whilst premium subsidy is the most common intervention, other enabling measures are important, such as the legal and regulatory framework, reinsurance, technical and administrative assistance, and linkages to government extension services in agriculture, animal health or meteorology (Dick, Wang, 2010). The public support of agricultural risk management in less developed countries with high weather sensitivity and high importance of agriculture for households are especially provided World Bank and FAO incentives (Larson, Anderson, Varangis, 2004). In less developed countries, World Bank together with micro-financing institutions test new insurance products based on weather indices (Miranda, Gonzalez-Vega, 2011; Sarris, 2013; Bobojonov, Aw-Hassan, Sommer, 2014; Norton et al., 2014). However, the index insurance in agriculture suffers from relatively low ability to reduce volatility of crop yields because of wide spectrum of non-weather factors affecting farm yields (Elabed et al., 2013).

The agricultural insurance and its public support should gain holistic visibility. It means that insurance

\footnotetext{
${ }^{1}$ In the Czech Republic it is the Act No. 166/1999 Coll., Veterinary Act, $\S 67,68$.
}

is not separate risk management tool. There are many other risk management tools for normal, marketable and catastrophic risks (OECD, 2009). The support of agriculture is included in Common Agricultural Policy of the EU after 2014 together with other risk management tools, e. g. mutual funds (Meuwissen, Assefa, van Asseldonk, 2013) and income stabilization tool (Finger, El Benni, 2014). Nevertheless, the alternative risk management tools are not accepted in all EU countries. Moreover, farmers can use direct payments or other subsidies are income risk management tools (Keeney, 2000, Špička, Boudný, Janotová, 2009, Řezbová, Tomšík, 2012).

In the field of agricultural risk management, cooperation between the private and public sector is generally recommended. The cooperation between public and private sector takes either a form of public-private partnership (Nussbaum, 2007) or a form of indirect cooperation through premium subsidies. In general, governments try to reduce the ad-hoc assistances for the agricultural sector. On the other hand, farms face some systematic risks which are commercially uninsurable. So, there should be public assistance for farmers facing systematic risks, such as drought.

In the Czech Republic, agricultural insurance is an important risk management tool. It is offered by several commercial insurance companies and it is supported from public sources, especially through the program "Support of insurance" provided by the Support and Guarantee Agricultural and Forestry Fund (PGRLF, Vávrová 2010).

The aim of the article is to evaluate the development of risk management support in agriculture in the Czech Republic in the period $2001-2013$. This article describes the current approaches to risk management in agriculture and analyzes the situation of agricultural insurance in the Czech Republic compared with the OECD recommendations and with the situation in other countries. Moreover, the article also tries to outline some possibilities for the future risk management scheme in the Czech Republic.

The article follows the common structure. After description of data and methodology, the forms of insurance in the Czech Republic, USA and European Unions are provided. Special part of results is devoted to the agricultural insurance scheme in the Czech Republic. The discussion about support of risk management tools in the new Rural Development Programme is provided at the end of results. Conclusions summarize 
the results and present suggestions for improvement of the Czech risk management system in agriculture.

\section{Materials and methods}

The method for identifying possible positive and negative impacts of agricultural risk management tools respects the holistic approach. The holistic approach examines relationships between sources of risk factors and risk management tools in agricultural businesses. The risks are divided into normal, marketable and catastrophic in the holistic approach. Marketable risks are designated as those risks whose effects can be eliminated or effectively reduce by the purchase of private insurance or futures contracts. Catastrophic risks generally affect a large number of farms throughout the region. It is usually not possible to reduce catastrophic risks through some private insurance, and thus government intervention is required. State aid can also help developing the private market of risk management tools effectively. Thus, support for insurance should be only temporary and after market stabilization should be reduced gradually. It is generally recommended not to use state intervention in the cases of normal risks, which should be managed at the farm level. The negative effects of such measures lies in displacing other proactive measures at farm level, such as the suppression of differentiated appropriate activities and sources of income. In this respect, the exceptions are the measures used in the assessment of income tax, mainly consisting of the possibility of averaging income over a period of several years (OECD, 2009).

Data provided by the PGRLF and the Czech Insurance Association (ČAP) was described using descriptive statistical methods (mean, standard deviation, coefficient of variation). The data sources for international comparison come from secondary sources made by the research centers for European Commission (Meuwissen, van Asseldonk, Huirne, 2008; Bielza Diaz-Caneja, 2009).

\section{Results and discussion}

\section{Forms of insurance for crop production}

The oldest type of crop insurance is the hail insurance. It covers the losses caused by single risk. Hail represents the potential risk of losing a substantial part of the crop production, especially for small farms. There is a relatively low incidence of occurrence and usually over the limited area which results relatively low premium rates for most of the field crops. Hail insurance can be extended to include other natural hazards (especially fire, flood, storm, landslide, damage through the winter or spring frost). The principle of calculation of damage remains the same - i.e. finding the actual damage caused by the insured risk. The premium for such insurance is proportionately higher. Generally, such insurance can be termed as crop loss insurance.

Another principle of insurance is the crop yield insurance. The object of crop yield insurance is to achieve the insured production volume, either at the farm level or at the level of an insured crop or group of crops. The compensation setting is based on the actual yield if the insured yield is not achieved. Such insurance was applied in the former Czechoslovakia in the years $1986-1990$ as "The comprehensive crop yield insurance", which was part of the mandatory insurance for agricultural holdings. Crop yield insurance is also broadly applied in the USA.

A different approach to crop insurance represents insurance based on weather indexes (weather insurance) or weather derivatives. In this type of insurance a desired weather characteristic is selected (e.g. rainfall over a defined period) and if the agreed threshold is not achieved, there is a graduated payment according to how much the actual result drops below the agreed threshold. This system appears as promising in areas with homogenous natural conditions where fluctuations in income are caused almost exclusively as a result of drought. The low transaction costs are an advantage because it is not necessary to identify any actual damage or yields. The indemnity is entirely based on the exact data measured at the meteorological station mentioned in the weather contract. The basis risk is connected with the incomplete correlation of actually yields obtained with the values of selected meteorological parameters measured at the meteorological station. Recent research results show that the spatial and production basis risks reduce the efficiency of the weather derivatives. The potential for expansion of weather derivatives remains in the low income countries of Africa and Asia with systemic weather risk (Špička, Hnilica, 2013). The results of efficiency of weather derivatives in Czech crop production shows similar efficiency like in the Germany (Mußhoff, Odening, Xu, 2006; Weber et al., 2008). Kimura and Antón (2011) recommend index insurance and weather derivatives as effective tools for risk-management of drought in Australian agriculture. Conversely, 
for heterogeneous landscape conditions that are characteristic in Czech agriculture, such an approach does not seem to have a big potential.

\section{United States of America}

The current system of crop insurance in the United States was established in 1938. The most often insured crops are corn, soybeans, and wheat, about $80 \%$ of the total area is insured (2008). The total value of premiums in 2008/09 was almost $\$ 10$ billion. The insurance coverage is $50 \%$ of the average yield and $55 \%$ of the expected crop prices in the basic CAT (Catastrophic) program. This basic coverage is fully subsidized by the state. Farmers can buy a higher level of insurance coverage with the Buy Up program, where it is possible to arrange insurance from 50\% to $85 \%$ of the average yield and from $55 \%$ to $100 \%$ of the expected price. The premium depends on the actual production history (APH) on the farm. In the case of price insurance the Risk Management Agency provides price forecasts. The government pays the administrative costs of agricultural insurance and secures the reinsurance.

In the U.S., many stakeholders rated the system very positively (Latham, 2010). They are some critical assessments from the point of view of moral hazard (Horowitz, Lichtenberg, 1993) or adverse selection (Just et al., 1999).

\section{Agricultural Insurance Systems in European Union}

In the European Union, individual states use very different systems of agricultural insurance. The diversity of approaches and institutional arrangements to agricultural risk management is given by the heterogeneity of risks which threaten Europe's farmers. In general, the higher risk of crop damage occurs in southern European countries, with particularly high risks of drought and other significant effects of extreme weather events. Hail plays an important role in the Central European countries and with regard to climate change more frequent occurrences of drought and local torrential rains are predicted. In contrast, countries in North Europe are less threatened by drought or hail. Therefore a consistent willingness to have a common risk management approach is improbable in the European Union.

There are of state established institutions which provided compulsory agricultural insurance in Greece and Cyprus (Vilhelm, 2006).

In most countries private agricultural insurance is supported by the public sector. Such a system is used in the Czech Republic, the Slovak Republic, Poland and Austria for example. In Austria, 50\% of the premium for crop insurance is subsidized from public sources (half from the state disaster fund, the second half from individual federal states). Unlike the situation in the Czech Republic the insurance subsidy is directly paid to the Austrian hail insurance company. Insurance covers more than $80 \%$ of agricultural land, of which more than $60 \%$ is insurance against more risks - freeze, hail, storm, flood, drought and other risks (Weinberger, 2009).

Spain has had a complex system of agricultural insurance based on the cooperation of the public and private sectors, with special institutions for its operation and development and state reinsurance, for more then thirty years. The system is financed by both the central Spanish government and from regional budgets. Total premiums for crop and livestock insurance under the system increased from about 3 billion $€$ in 1991 to almost 11 billion $€$ in 2008 and total support for increased insurance premiums over the same period ranged between 90 and 450 million $€$ (Antón, Kimura, 2011). The share of the insured value of the total production was $72 \%$ for cereals, $76 \%$ for fruit and $79 \%$ for livestock (Toraño, 2010).

On the other hand, in some countries, the agricultural insurance system operates on a purely commercial basis without government interference (e. g. in Germany, Great Britain and the Scandinavian countries). In some countries, such as in France and in the Netherlands, the government plays a significant role in providing insurance funds, created in part by compulsory contributions from farmers. In the European Union is not available an insurance solution covering fluctuations in prices of agricultural commodities offered unlike the situation in the United States.

The European Union, under the Common Agricultural Policy (CAP) allows support of agricultural insurance from national sources. The CAP Health Check measures in 2008 (article 68) allow to retain up to 10 per cent of national ceilings for direct payments to provide support for agricultural insurance or mutual funds for animal and plant diseases. The support may be paid up to $65 \%$ of the insurance premium, while the share of EU CAP can be up to $75 \%$.

The future public support of risk management in agriculture has been frequently discussed 
in recent years as a part of design of the new Rural Development Programme (RDP) for the period 2014-2020. Regulation (EU) No. 1305/2013 of the European Parliament and of the Council of $17^{\text {th }}$ December 2013 on Support for Rural Development by the European Agricultural Fund for Rural Development (EAFRD) and Repealing Council Regulation (EC) No 1698/2005 list the risk management support in Article 36. Support under this measure shall cover:

1. financial contributions to premiums for crop, animal and plant insurance against economic losses to farmers caused by adverse climatic events, animal or plant diseases, pest infestation, or an environmental incident;

2. financial contributions to mutual funds to pay financial compensations to farmers, for economic losses caused by adverse climatic events or by the outbreak of an animal or plant disease or pest infestation or an environmental incident;

3. an income stabilisation tool, in the form of financial contributions to mutual funds, providing compensation to farmers for a severe drop in their income.

"Support under point (a) of Article 36(1) shall only be granted for insurance contracts which cover for loss caused by an adverse climatic event, or by an animal or plant disease, or a pest infestation, or an environmental incident or a measure adopted in accordance with Directive 2000/29/EC to eradicate or contain a plant disease, or pest which destroys more than $30 \%$ of the average annual production of the farmer in the preceding three-year period or a three-year average based on the preceding five-year period, excluding the highest and lowest entry. Indexes may be used in order to calculate the annual production of the farmer. The calculation method used shall permit the determination of the actual loss of an individual farmer in a given year." Unfortunately, the $30 \%$ threshold of a loss from the average annual production of the farmer is not suitable for EU countries with high share of large agricultural companies (Czech Republic, Slovakia) since the probability of damage exceeding $30 \%$ of the average annual production is low.

Mutual funds for adverse climatic events, animal and plant diseases, pest infestations and environmental incidents are eligible for support if a mutual fund:

- is accredited by the competent authority in accordance with national law;

- has a transparent policy towards payments into and withdrawals from the fund;
- has clear rules attributing responsibilities for any debts incurred.

The financial contributions of mutual funds may only relate to:

- he administrative costs of setting up the mutual fund, spread over a maximum of three years in a degressive manner;

- the amounts paid by the mutual fund as financial compensation to farmers. In addition, the financial contribution may relate to interest on commercial loans taken out by the mutual fund for the purpose of paying the financial compensation to farmers in case of crisis.

Moreover, the condition of support of risks which destroy more than $30 \%$ of the average annual production is compulsory for all risk management tools in the RDP! The Dutch experience (Meuwissen, Assefa, van Asseldonk, 2013) shows that mutuals are well equipped to insure risks that are uninsurable in the commercial market. This is especially true for animal and crop disease risks. However, experience has demonstrated that mutuals are not always successful, even with substantial public support. Lack of members caused several mutuals to be discontinued only a few years after their foundation. In order to secure the benefits of mutuals, it is shown that there is a need to carefully balance size of risk, affordability of premiums, financial robustness and solidarity.

Finally, income stabilisation tools are closely connected to mutual funds. Supported income stabilisation tool shall only be granted where the drop of income exceeds $30 \%$ of the average annual income of the individual farmer in the preceding three-year period or a three-year average based on the preceding five-year period excluding the highest and lowest entry. Finger and El Benni (2014) conclude that income stabilisation tolls significantly reduce income inequality, in particular by increasing lower quantiles of the income distribution. Nevertheless, the countries with low level of cooperation and integration in agriculture will not apply support of establishing mutual funds and income stabilisation tool (e. g. the Czech Republic).

\section{Agricultural insurance in the Czech Republic}

Agricultural insurance in the Czech Republic has operated on a voluntary basis in the Czech Republic since 1991. Formerly, the agricultural insurance had the form of mandatory insurance for all agricultural holdings (i.e., especially agricultural cooperatives 
and state farms) and was operated by the state insurance company until 1990. Seven commercial insurers offered agricultural insurance actively in 2013. According to the Insurance Act, agricultural insurance can be offered by any commercial insurance company licensed by the Czech National Bank and issued relevant insurance conditions. State reinsurance does not exist in the Czech Republic, unlike in Spain or United States. Creating a state reinsurance company for the reinsurance of agricultural risks was one of the proposals when deciding the optimal form of state involvement in agricultural insurance.

Agricultural insurance had no state support in the period $1991-1999$. The Ministry of Agriculture began support through the No. 8 subsidy program - the animal contagious diseases fund and subsidies for agricultural insurance from 2000. The subsidy for agricultural insurance was conditioned by the non-spending of financial resources for superior subsidies. No subsidy for agricultural insurance was paid for this reason in 2003. The state-owned Support and Guarantee

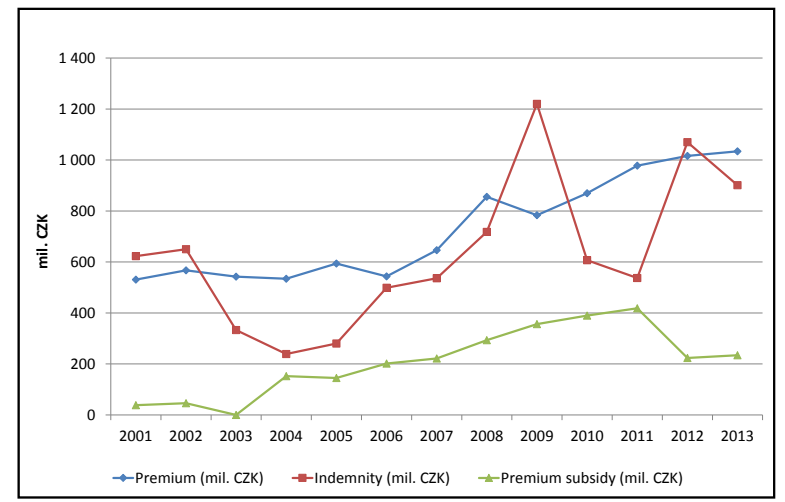

Source: ČAP, PGRLF, own calculations

Figure 1: Crop insurance in the Czech Republic between 2001 and 2013.
Agricultural and Forestry Fund (PGRLF) introduced instead a new program "Support of insurance" in 2004. This support of insurance was implemented as the retroactive reimbursement of premium costs paid by the insured farmer for crop insurance (insurance against hail, fire, storm, flood, landslides, spring frost or frost) and livestock insurance (insurance against death or being killed as a result of a natural disaster, or other dangerous diseases of an infectious or parasitic origin). The purpose of this support is to make insurance protection for farmers more accessible. The support from 2004 increased from $30 \%$ of the premium for crop insurance and $15 \%$ of the premium for livestock insurance to $50 \%$ for both types of insurance since 2009. Subsidy is available for small and medium holdings and it is provided only for insurance premium, that was really paid, which implies, that the real share of support on premium written is less than $50 \%$. Figure 1 shows the development of the crop insurance; figure 2 provide an overview on livestock insurance in the period $2001-2013$.

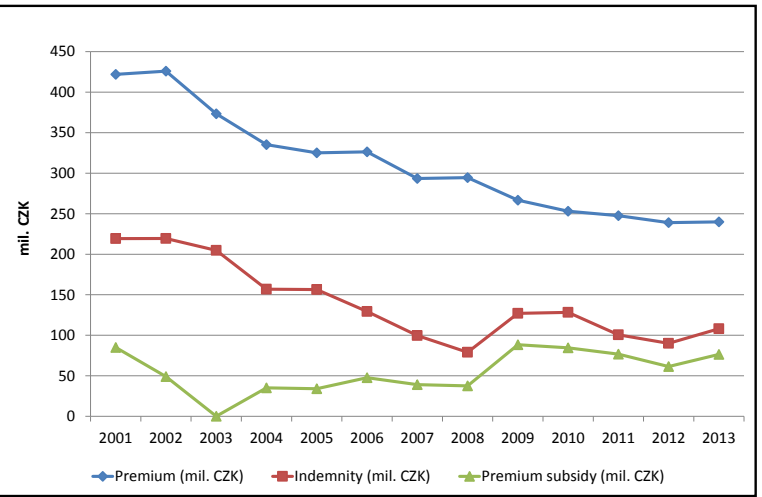

Source: С̆AP, PGRLF, own calculations

Figure 2: Livestock insurance in the Czech Republic between $2001-2013$.

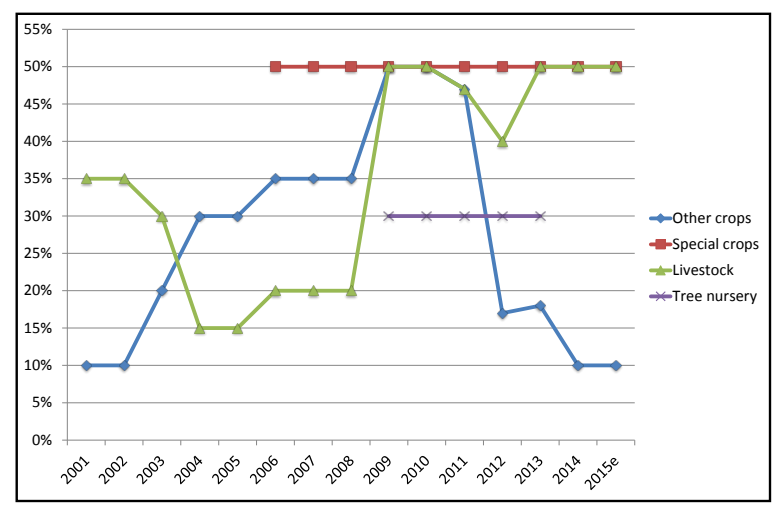

Source: ČAP, PGRLF, own calculations

Figure 3: Rates of premium subsidies in the Czech Republic. 
Figure 3 shows the development of rates of premium subsidies in agricultural insurance provided by the PGRLF in the period $2001-2013$. The years 2014 and 2015 are estimates.

The crop insurance premium volumes have increased by $94.8 \%$ from 2001 to 2013 . The fluctuation of loss ratio was relatively high. The losses paid were higher then the premiums in four of thirteen years. Alternatively, livestock insurance showed a steady decline. The loss ratio in livestock insurance has been relatively low and stable. A higher loss ratio (at most 55\% of total premiums in 2003) was seen in the years from 2001 to 2003, particularly in connection with cases of BSE. The overall downward trend in premiums corresponds to the decreasing numbers of farm animals in the Czech Republic.

Tab. 1 shows differences between crop and livestock insurance. The differences are described through sums, means, standard deviations and coefficients of variation of the parameters of agricultural insurance in the Czech Republic in last thirteen years, which illustrates the above mentioned characteristics.

The coefficient of variation of indemnity from the crop insurance is 0.462 whereas the coefficient of variation of indemnity from the crop insurance is 0.346. It is clearly shown that crop production is riskier than livestock production since the weather affects the crop yields rather than livestock production.

The share of insured livestock was estimated at $80 \%$. Private insurance refers as well to cases of slaughter emergency of animals by the outbreaks of dangerous diseases which are compensated by the state according to the Veterinary Act. Compensation by the state together with the indemnity of the affected farmer's private insurance contract usually covers the damage not only of the lost animals but also the damage caused by the disruption of animal production. Unlike this solution the private business interruption insurance is offered for such cases in some other EU countries. The epizootic diseases are usually a standard exclusion in private livestock insurance in many countries.

The increasing rate of premium subsidies of crop insurance from 2001 to 2010 had a positive effect on the evolution of the total acreage of insured crops. The data refers to crops grown on arable land, vineyards, hop gardens and orchards. In 2010, the acreage of insured crops reached 1.5 million hectares. The share of the insured area was $48 \%$, taking the total area of arable land, vineyards, hop fields and fruit orchards from the Czech Institute of Surveying, Mapping and Cadastre (ČÚZK). The share was $58 \%$ according to data from LPIS, which is related to the registered users of agricultural land and better represents the market potential for crop insurance. In recent years, the acreage of insured crops has slightly increased and reached 1.6 million hectares in 2013.

On the basis of the development of crop insurance penetration it can be noted that the premium subsidy has met its purpose and helped to develop the agricultural insurance market, especially crop insurance. This argument is valid only for actual insurable risks. Commercial insurance does not cover some important risks to crops in the Czech Republic; in addition to price risk, the risk of drought particularly but also the risk of rains at harvest time. The risk of draught, especially, has a much more systematic character than most of the present commercially insurable risks. This should lead to more government attention in this area.

There are various possibilities for further development of agricultural insurance. The relatively high support of commercial insurance could lead to the extension of the insurable risks in agricultural insurance products, as in Austria. Another possibility is the creation of a public fund as a financial instrument which would allow farmers to be compensated

\begin{tabular}{|l|l|c|c|c|c|}
\hline \multicolumn{2}{|l|}{ Parameter } & Sum (mil. CZK) & Mean (mil. CZK) & $\begin{array}{c}\text { Standard deviation } \\
\text { (mil. CZK) }\end{array}$ & $\begin{array}{c}\text { Coefficent } \\
\text { of variation }\end{array}$ \\
\hline \multirow{2}{*}{ Crop insurance } & premium & 9494.8 & 730.4 & 198.7 & 0.272 \\
\cline { 2 - 6 } & indemnity & 8212.4 & 631.7 & 292.0 & 0.462 \\
\hline Livestock insurance & premium & 4042.7 & 311.0 & 64.9 & 0.209 \\
\hline & indemnity & 1818.7 & 139.9 & 48.5 & 0.346 \\
\hline
\end{tabular}

Source: ČAP, PGRLF, own calculations

Table 1: Differences between development of premium and indemnity of crop and livestock insurance in the period $2001-2013$. 
for uninsurable risks (Prášilová, Hošková, 2010). The Agricultural Association of the Czech Republic suggests in this connection the creation of tools for risk and crisis management, with particular emphasis on coverage of uninsurable risks ${ }^{2}$ from state budget after 2014 .

The Czech Republic will not adapt support of risk management tools from the RDP due to specific size structure of Czech farms. The premium subsidies will be still provided from state budget by PGRLF. In the period 2014-2020, the ad hoc aids from the state budget are allowed by Framework program for dealing with risks and crises in agriculture - no. SA.37221 (2013/N). Estimated total budget for ad-hoc aids for the whole period 2014 - 2020 is 12250 mil. CZK (= approximately 500 mil. $€$ ). The Framework enables to compensate losses caused by:

- natural disasters (earthquakes, landslides, floods, storm / hurricane and landslides),

- extraordinary events (major fires and industrial accidents),

- adverse weather events (heavy rain, flooding, drought, frost, ice, ground frost, hail).

Ad-hoc aid will be paid in the form of direct payments. Each applicant has to give confirmation on indemnity or risk uninsurability otherwise the aid will be reduced up to $50 \%$.

\section{Conclusion}

The aim of the article is to evaluate the development of risk management support in agriculture in the Czech Republic in the period 2001 - 2013. This article describes the current approaches to risk management in agriculture and analyzes the situation of agricultural insurance in the Czech Republic compared with the OECD recommendations and with the situation in other countries.

The diversity of approaches to risk management in agriculture in the world and the countries of the European Union reflects various risks that farmers face in different countries. In the current period, the major sources of risk are the growing impacts of climate change and globalization of markets. The first case causes more frequent extreme weather events; the latter generates fluctuations in commodity prices and less dependence on the local production. Cooperation between the private and public sectors is generally

\footnotetext{
${ }^{2}$ For losses caused by drought was paid 5 billion CZK in form of ad hoc state aid in 2000 .
}

considered as the optimal way to offer more effective tools of risk management. Normal risks, marketable risks and catastrophic risks specify the role of risk management at farm level, private market level and state intervention. The boundary between insurable and uninsurable risks is vague and different in various countries. For example, drought is often considered to be a systematic risk and therefore uninsurable, which is the case of the Czech agricultural insurance market. A similar conclusion applies to the risk of dangerous animal diseases. In this case the risk in the Czech Republic is generally insurable.

The Czech experience shows that support from public sources has helped to develop the agricultural insurance market. It would be desired to use the public sources for the heretofore uninsurable risks and to find the possibility for its insurability or to create a fond for such losses. In the case of livestock diseases the subsidized insurance covers also such cases which are indemnified by state according the Veterinary Act. A better solution would be to replace current livestock insurance by business interruption insurance for animal production.

The future of risk management support in the Czech Republic consists in ongoing premium subsidies from the state budget, state-financed ad hoc aids (or other equivalent tool for uninsurable risks), support of risk prevention from disease fund for livestock production and recovery fund for crop production. The direct payments will help farmers to increase the income level. The Czech Republic will not use any risk management support from the new Rural Development Programme in the period $2014-2020$. Furthermore, it would be appropriate to focus attention on the creation of state co-financed instruments covering catastrophic losses. A possible solution is a creation of fund for uninsurable risks. The new instrument would replace the ad hoc state aid efficiently and effectively.

\section{Acknowledgements}

Support for this article came also from the Internal research project IAEI No. 4/1275/2014 "Allocating of costs of ancillary activities and overhead cost to operations in plant and livestock production". 
Corresponding author:

Ing. Václav Vilhelm, CSc.

Department of Economics of Agriculture, Institute of Agricultural Economics and Information, Prague

Mánesova 75, 12000 Prague 2, Czech Republic

E-mail:vilhelm.vaclav@uzei.cz

\section{References}

[1] Antón, J., Kimura S. Risk Management in Agriculture in Spain. Paris: OECD Food, Agriculture and Fisheries Working Papers. 2011, No. 43, OECD Publishing. doi: 10.1787/5kgj0d57w0wd-en.

[2] Bobojonov, I., Aw-Hassan, A., Sommer, R. Index-based insurance for climate risk management and rural development in Syria. Climate and Development. 2014, Vol. 6, No. 2, p. 166-178. ISSN 1756-5529.

[3] Bielza Diaz-Caneja, M., Conte, C. G., Gallego Pinilla, F. J., Stroblmair, J., Catenaro, R., Dittmann, C. Risk Management and Agricultural Insurance. Ispra: European Commission - Joint Research Centre - Institute for the Protection and Security of the Citizen, 2009. ISBN 978-92-79-12860-8.

[4] Dick, W. J., Wang, W. Government interventions in agricultural insurance. Agriculture and Agricultural Science Procedia.2010, Vol. 1, p. 4-12. ISSN 2210-7843.

[5] Elabed, G., Bellemare, M. F., Carter, M. R., Guirkinger, C. Managing basis risk with multiscale index insurance. Agricultural Economics (United Kingdom). 2013, Vol. 44, No. 4-5, p. 419-431. ISSN 0169-5150.

[6] Finger, R., El Benni, N. A note on the effects of the income stabilisation tool on income inequality in agriculture. Journal of Agricultural Economics, 2014, Vol. 65, No. 3, p. 739-745. ISSN 0021-857X.

[7] Horowitz, J., Lichtenberg, E. Insurance, Moral Hazard, and Chemical Use in Agriculture. American Journal of Agricultural Economics, 1993, Vol. 75, No. 4, p. 926 - 935. ISSN 0002-9092.

[8] Iturrioz, R. Agricultural Insurance. Primer series on insurance. 2009, No. 12. The World Bank, Washington DC 2009. Without ISSN/ISBN.

[9] Just, R. E., Calvin, L., Quiggin, J. Adverse Selection in Crop Insurance: Actuarial and Asymmetric Information Incentives. American Journal of Agricultural Economics. 1999, Vol., 81, No. 4, p. 834 - 849. ISSN 0002-9092.

[10] Keeney, M. The Distributional Impact of Direct Payments on Irish Farm Incomes. Journal of Agricultural Economics. 2000, Vol. 51, No. 2, p. 252-263. ISSN 0021-857X.

[11] Kimura, S., Antón J. Risk Management in Agriculture in Australia. Paris: OECD Food, Agriculture and Fisheries Working Papers, 2011, No. 39, OECD Publishing. doi: 10.1787/5kgj0d8bj3d1-en.

[12] Larson, D. F., Anderson, J. R., Varangis, P. Policies on managing risk in agricultural markets. World Bank Research Observer. 2004, Vol. 19, No. 2, 2004, p. 199-230. ISSN 0257-3032.

[13] Latham, B. Der Ernteversicherungsprogramm in den USA. Internationales Agrarversicherungssymposium „Risikomanagement durch Versicherungslösungen”, Wien, 21. 1. 2010. [Online]. Available: https://www.hagel.at/site/files/avs/DE_1_Latham.pdf [Accessed 10 Nov. 2014).

[14] Meuwissen, M. P. M., van Asseldonk, M. A. P. M., Huirne, R. B. M. Income Stabilisation in European Agriculture. Design and Economic Impact of Risk Management Tools. Wageningen: Wageningen Academic Publishers, 2008. 223 p. ISBN 978-90-8686-079-1.

[15] Meuwissen, M. P. M., Assefa, T. T., Van Asseldonk, M. A. P. M. Supporting Insurance in European Agriculture: Experience of Mutuals in the Netherlands. EuroChoices. 2013, Vol. 12, No. 3, p. 10-16. ISSN 1478-0917.

[16] Miranda, M. J., Gonzalez-Vega, C. Systemic risk, index insurance, and optimal management of agricultural loan portfolios in developing countries. American Journal of Agricultural Economics. 2011, Vol. 93, No. 2, p. 399-406. ISSN 0002-9092. 
[17] Mußhoff, O., Odening, M., Xu, W., Zur Quantifizierung des Basisrisikos von Wetterderivaten, Tech. Rep. No. 14947, German Association of Agricultural Economists, Giessen, Germany, 2006. Without ISSN/ISBN.

[18] Norton, M., Osgood, D., Madajewicz, M., Holthaus, E., Peterson, N., Diro, R., Mullally, C., Teh, T.-L., Gebremichael, M. Evidence of Demand for Index Insurance: Experimental Games and Commercial Transactions in Ethiopia. Journal of Development Studies. 2014, Vol. 50, No. 5, p. 630-648. ISSN 0022-0388.

[19] Nussbaum, R. Public private partnership (PPP) for prevention and insurance of natural catastrophes in Europe. Houille Blanche. 2007, No. 2, p. 58-63. ISSN 0018-6368.

[20] OECD. Managing risk in agriculture: A holistic approach, OECD, Paris, 2009. ISBN 978-92-6407-530-6.

[21] Prášilová, M., Hošková, P. Development analysis and a system solution design for agricultural insurance in CR. Acta Universitatis Agriculturae et Silviculturae Mendelianae Brunensis. 2010, Vol. 58, No. 6, part 2, p. 379-388. ISSN 1211-8516.

[22] Sarris, A. Weather index insurance for agricultural development: Introduction and overview. Agricultural Economics (United Kingdom). 2013, Vol. 44, No. 4-5, p. 381-384. ISSN 0169-5150.

[23] Smith, V. H., Glauber, J. W. Agricultural insurance in developed countries: Where have we been and where are we going? Applied Economic Perspectives and Policy. 2012, Vol. 34, No. 3, p. 363-390. ISSN 2040-5790.

[24] Špička, J., Boudný, J., Janotová, B. The role of subsidies in managing the operating risk of agricultural enterprises. Agricultural Economics - Czech. 2009, Vol. 55, No. 4, p. 169 - 179. ISSN 0139-570X.

[25] Špička, J., Hnilica, J. A Methodical Approach to Design and Valuation of Weather Derivatives in Agriculture. Advances in Meteorology. 2013, Vol. 2013, 8 p. Article ID 146036. ISSN 1687-9309.

[26] Řezbová, H., Tomšík, K. Impact of complementary national direct payments on cattle breeding sector. Agris On-line Papers in Economics and Informatics. 2012, Vol. 4, No. suppl. spl. 4, p. 95-106. ISSN 1804-1930.

[27] Toraño, A. F. Das Ernteversicherungssystem in Spanien. Internationales Agrarversicherungssymposium „Risikomanagement durch Versicherungslösungen”, Wien, 21. 1. 2010. Without ISSN/ISBN.

[28] Vávrová, E. Development of the agricultural Insurance market in the Czech Republic. Acta Universitatis Agriculturae et Silviculturae Mendelianae Brunensis. 2010, Vol. 58, No. 6, part 2, p. 613-624. ISSN 1211-8516.

[29] Vilhelm, V. Sympozium Světové asociace ovlivňování počasí. Pojistný obzor. 2006, Vol. 83, No. 5, p. 12 - 13. ISSN 0032-2393.

[30] Weber, R., Kraus, T., Mußhoff, O., Odening, M., Rust, I. Risikomanagement mit indexbasierten Wetterversicherungen - Bedarfsgerechte Ausgestaltung und Zahlungsbereitschaft. Risikomanagement in der Landwirtschaft. Schriftenreihe Band 23, Rentenbank, Frankfurt a. M., 2008. [Online] Available: http://www.rentenbank.de/cms/dokumente/10011465_262637/b4993161/ Schriftenreihe_Band_23.pdf [Accessed 10 Nov. 2014].

[31] Weinberger, K. Management von Wetterrisiken in Anbetracht des Klimawandels und der GAP - Reform. „Ländlicher Raum“ Online-Fachzeitschrift des Bundesministeriums für Landund Forstwirtschaft, Umwelt und Wasserwirtschaft. Jahrgang 2009. [Online] Available: http://www. bmlfuw.gv.at/land/laendl_entwicklung/Online-Fachzeitschrift-Laendlicher-Raum/archiv/2009/ weinberger.html [Accessed 10 Nov. 2014].

[32] Yildirak, K., Gulseven, O. Indemnity payments in agricultural insurance: Risk exposure of EU states. Actual Problems of Economics. 2012, Vol. 127, No. 1, p. 381-388. ISSN 1993-6788. 